\title{
Biochemical Characterization of Swamp Buffalo (Bubalus carabanesis) Semen
}

\author{
Manna Baruti $^{1 *}$, B. C. Deka1, Manjyoti Bhuyan ${ }^{1}$, Shantanu Tamuly², \\ R. K. Biswas ${ }^{1}$ and S. Sinha ${ }^{1}$ \\ ${ }^{1}$ Department of Animal Reproduction, Gynaecology and Obstetrics, College of Veterinary \\ Science, Assam Agricultural University, Khanapra, Guwahati-22, Assam, India \\ ${ }^{2}$ Department of Veterinary Biochemistry, College of Veterinary Science, Assam Agricultural \\ University, Khanapra, Guwahati-22, Assam, India \\ *Corresponding author
}

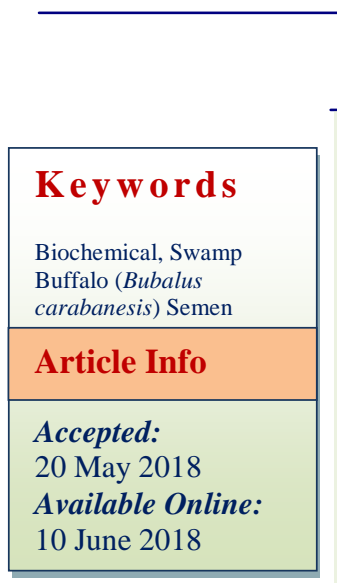

A B S T R A C T

Four Swamp buffalo bulls aged 5 to 8 years were used to study the fresh semen as well as biochemical characteristics. A total of 60 ejaculates comprising 15 from each bull evaluated for fresh semen characteristics and a total of 40 ejaculates comprising 10 from each bull were used for evaluation and biochemical characterization. For Biochemical constituents of semen the AST and ALT activities, total protein, total cholesterol and total lipid concentration were estimated in seminal plasma of fresh semen and the overall mean values of the AST and ALT activities and total protein, total cholesterol and total lipid concentration were $26.05 \pm 0.74 \mathrm{U} / \mathrm{L}, 49.14 \pm 1.72 \mathrm{U} / \mathrm{L}, 3.44 \pm 0.02 \mathrm{mg} / \mathrm{ml}, 23.12 \pm 0.65 \mathrm{mg} / \mathrm{dl}$ and $2.20 \pm 0.07 \mathrm{mg} / \mathrm{ml}$ respectively in seminal plasma of fresh semen. The sperm membrane extract and seminal plasma proteins of fresh semen characterized by SDS-PAGE. Seven protein bands in seminal plasma and eight protein bands were identified in sperm membrane extract of the Swamp buffalo semen.

\section{Introduction}

The geographical distribution of Swamp buffalo (Bubalus carabanesis) ranges from Brahmaputra valley of Assam (India) to the Yangtze valley of China of Southeast Asia (Yang et al., 2008). The world buffalo population is estimated at over 170 million (FAO, 2004), of this 95 per cent is located in Asia. India has 97.9 million buffalo (Livestock census, 2003) constituting approximately 57.59 per cent of the total world population. The buffalo population in Assam is comprised of 6, 17, 109 Swamp and 60, 560 crossbred (Swamp X Riverine) buffaloes. The welldefined breeds of Riverine buffaloes found in India are known worldwide for their higher milk yielding potentialities. On the other hand, Swamp types of buffaloes (Bubalus carabenesis) present in the state are poor milk producers. They serve as a source of draught power. Since the number of chromosome in Riverine (50) and Swamp (48) buffaloes are different, the production performances of Swamp buffaloes of Assam could be improved through selection of superior animals. But the 
most important limiting factor for improving the productivity of Swamp buffaloes is the non-availability of sufficient number of breeding bulls having superior genetic makeup. Routinely used traditional semen quality tests provide limited information about potential fertility of bulls. Computer assisted semen analysis (CASA) commonly used these days to evaluate semen quality, does not provide high correlation or even consistent results with bull fertility index. The biomolecular investigation of seminal plasma and spermatozoal content signifies a new world of male infertility. Several proteins identified in seminal plasma are positively and also negatively correlated with fertility. The soluble and structural proteins have a notifiable role in sperm metabolism which influenced fertility as reported in bull (Killian et al., 1993) and buffalo (Asadpour et al., 2007). A number of plasma proteins have been studied which act as molecular markers of fertility in different species including Riverine buffaloes. However, up till now no detail study was reported in proteomics of semen in Swamp buffalo. Although a few studies have been reported on proteomics of frozen semen in bulls (Park et al., 2012), riverine buffalo bulls (Dhanju et al., 2001), ram (Goularte et al., 2014), and buck (Deori, 2015), perusal of available literature revealed no such study in Swamp buffalo bulls. In view of the above, the present study on the biochemical and proteomics in semen of Swamp buffalo bulls has been undertaken with the following objectives to evaluate certain biochemical parameters of Swamp buffalo semen and SDSPAGE of Seminal plasma and Sperm membrane extract.

\section{Materials and Methods}

\section{Study location}

A total of four Swamp buffalo bulls aged five to eight years maintained at "Network Project on Swamp Buffalo", College of Veterinary Science, Assam Agricultural University, Khanapara, Guwahati-22 were used in the present study. The bulls were thoroughly examined for their general and reproductive health prior to selection in the study from September, 2016 to July, 2017. The bulls were maintained under uniform feeding and management practices throughout the period of study. Semen was collected from each bull twice a week with the help of a standard artificial vagina (IMV technologies, France). One to two numbers of false mounts were allowed prior to collection of semen.

\section{Evaluation of semen}

Semen was evaluated immediately after collection and after freezing. Immediately after collection, semen was evaluated for ejaculate volume, mass activity, initial sperm motility, sperm concentration, hypo osmotic swelling test and intact acrosome. Selected good quality semen samples are only subjected for freezing and biochemical characterization. A total 60 ejaculates having volume $1.5 \mathrm{ml}$ or more with $3+$ or more mass activity were only used for processing and freezing in the study.

\section{Separation of seminal plasma and sperm pellet}

The semen sample was centrifuged at 30 , $000 \times \mathrm{g}$ for $30 \mathrm{~min}$. The supernatant was kept in fresh tube and sperm pellet was redissolved in distilled water for further analysis. The seminal plasma and sperm pellet were kept in $-20^{\circ} \mathrm{C}$ till further analysis. The procedure was also followed in separation of extracellular fluid and sperm pellet in frozen semen.

\section{Biochemical evaluation of seminal plasma}

The AST and ALT activities in seminal plasma of fresh semen and extracellular fluid 
of frozen semen was estimated. The AST and ALT activities were estimated by using AST \& ALT kit (Modified International Federation of Clinical Chemistry, IFCC method, Aspen laboratories). The total protein in seminal plasma of fresh semen and extracellular fluid of frozen semen was estimated by the method of Lowry et al., (1951) and was expressed in $\mathrm{g} / \mathrm{dl}$. The total cholesterol content of seminal plasma of fresh semen and extracellular fluid of frozen semen was determined by using Chemical kit (CHOD-POD/Phosphotungstate method) of Medsource Ozone Biomedical Pvt. Ltd., Sector- 3, Faridabad, Haryana. The total lipid content of seminal plasma of fresh semen and extracellular fluid of frozen semen was estimated following the method described by Frings and Dunn (1970). Estimation of AST, ALT, total protein, total Cholesterol and total lipid in the extra cellular fluid of frozen semen was determined by subtracting the total protein concentration of frozen thawed extender containing egg yolk.

SDS-PAGE of seminal plasma of fresh semen and extra cellular fluid of frozen semen and sperm membrane extract of fresh and frozen semen

Vertical slab of glass gel apparatus (Atto Corporation) were cleaned properly with $70 \%$ ethyl alcohol and were assembled with the spacers and clamped together. Freshly prepared resolving gel was poured into glass mould above 1/3 margin and allowed to polymerize. Triple glass distilled water was poured to prevent bubbling. After polymerization distilled water was removed and freshly prepared stacking gel was poured into the remaining upper margin of the glass mould. A comb was inserted between the glasses and kept for polymerization. The comb was carefully pulled from polymerized gel when it was ready to be processed for electrophoresis. The gel was attached to the electrophoresis tank and the reservoir of the electrophoresis tank was filled with electrophoresis buffer $1 \mathrm{X}$ Tris Glycine buffer (pH 8.3). Prepared $15 \mu 1$ sample was loaded. The gel was run in 4 volts per $\mathrm{cm}$. and followed by 8 volt per $\mathrm{cm}$ until the marker dye migrated the desired distance. The gel was stained with Coomasie brilliant blue R-250 (Sigma) and calibrated using molecular weight marker (High range protein marker, 14-220 Da, SRL).

\section{Statistical analysis}

Data obtained were analyzed in SAS Enterprise Guide-4.3 software.

\section{Results and Discussion}

The overall mean ejaculate volume of semen in four Swamp buffalo bulls $(1.57 \pm 0.03 \mathrm{ml})$ recorded in the present study (Table 2) was comparable with that reported by Nordin et al., (1996), Das et al., (2007), Majumdar (2012) and Talukdar (2014) in Swamp buffalo; Mahmoud (1952) in Nili-Ravi buffalo, and Chaudhary (1979) in Murrah buffalo bulls. However, higher values of ejaculate volume were reported by earlier workers in Swamp (Jainudeen et al., 1982, Koonjaenak et al., 2007), Murrah (Dhami et al., 1998, Ravimurugan et al., 2008, Selvaraju et al., 2008), Nili-Ravi buffalo (Addel et al., 2009) and Surti (Dhami and Kodagali 1988; Purohit et al., 1998) buffalo bulls.

The mean overall mass activity score (0-4+ scale) in the semen of Swamp buffalo bulls (3.57+) recorded in the present study was in close proximity with that reported in Swamp (Das et al., 2007, Majumdar 2012 and Talukdar 2014) and Murrah (Bhosrekar 1980, Sahu and Pandit 1997) buffalo bulls. The mean value obtained in the present study was lower than the values reported by earlier workers in Thai Swamp (Koonjaenak et al., 2007), and Murrah (Rao et al., 1996, Dhami et 
al., 1998, Purohit et al., 1998, Pratap et al., 1999 and Javed et al., 2000) buffalo bulls and higher than the values reported by Singh et al., (1992) in Swamp buffalo bulls.

The mean overall initial sperm motility in Swamp buffalo bulls $(73.45 \pm 1.00 \%)$ recorded in the present study was in close confomity with that reported by earlier workers in Swamp (Koonjaenak et al., 2007, Majumdar 2012), Murrah (Gupta and Misra 2007, Shukla and Misra 2007) and in Surti (Dhami and Kodagali 1988) buffalo bulls. The mean value obtained in the present study was lower than the values reported by earlier workers in Swamp (Koonjaenak 2006, Talukdar 2014), Murrah (Rao et al., 1996, Pratap et al., 1999, Reddy et al., 2010) and Surti (Purohit et al., 1998), Nili-Ravi (Hashemi et al., 2007) and Tarai (Singh and Gupta 2008) buffalo bulls. The mean value obtained in the present study was higher than the values reported by earlier workers in Swamp buffalo (Das et al., 2007, Nordin et al., 1990).

The mean concentration of spermatozoa recorded $(1138.17 \pm 15.20$ million per $\mathrm{ml})$ in the present study was comparable with the value reported by Koonjaenak et al., (2007) and Talukdar (2014) in Swamp buffalo bulls and Pratap et al., (1999) in Murrah buffalo bulls. The mean value obtained in the present study was lower than that reported by Selvaraju et al., (2008) in Murrah buffalo bulls but higher than that reported by Nordin et al., (1990) and Majumdar (2012) in Swamp buffalo bulls and Shetti et al., (1987) in Murrah buffalo bulls.

The overall mean per cent of HOST-reacted sperm in four Swamp buffalo bulls $(76.97 \pm$ 0.43 ) recorded in the present study was in close proximity to the values reported by Nordin et al., (2006) in Swamp and Singh and Gupta (2008) in Tarai buffalo bulls. However, the present value was higher than that reported in Murrah buffalo by Pratap et al., (1999), Gupta and Mishra (2007) and Cheede et al., (2009), Jafarabadi and Mehsana by Dhami et al., (2011), in Kundhi buffalo by Rehman et al., (2012) and Nili-Ravi buffalo by Iqbal et al., (2009) but lower than that reported in Swamp buffalo (Ahmed, 2011 and Talukdar, 2014), in Murrah buffalo (Reddy et al., 2010).

The overall mean live sperm percentage $(82.85 \pm 0.25)$ recorded in the present study was close to the values reported in Swamp (Das et al., 2013 and Talukdar 2014) and Murrah (Rattan et al., 1980, Vyawanare et al., 1989) buffaloes. However, the present value was higher than the values reported by earlier workers in Swamp (Nordin et al., 1990, Das et al., 2007), Murrah (Pratap et al., 1999, Tomar et al., 2000, Gupta and Misra 2007), Surti buffaloes (Purohit et al., 1998). On the other hand, the present value was lower than the value reported in Swamp (Ahmed 2011, Dutta et al., 2013), Murrah (Singh et al., 1992, Singh et al., 1994, Shukla and Misra 2007) and Tarai (Singh and Gupta 2008, Beerendra et al., 2011), Jafarabadi (Dhami et al., 2011) buffalo bulls.

The overall mean percentage of cold shock resistant sperm in of Swamp buffalo semen was $40.62 \pm 0.18$ per cent. The percentage of cold shock resistant spermatozoa in the present study was higher than that reported by Nordin et al., (1990), Koonjaenak (2006), Ahmed (2011) and Talukdar (2014) in Swamp buffalo and in Murrah buffalo as reported by Tomar and Misra (1971), Monji et al., (1980) and Singh et al., (1994). The variations in percentage of cold shock resistant spermatozoa could be due to difference in breed and/or method of rendering cold shock to spermatozoa (Monji et al., 1980).

The overall mean percentage of intact acrosome in four Swamp buffalo bulls was 
$82.01 \pm 0.19$. The present value was similar to that reported by Talukdar (2014). The present value was higher than the values reported by Rasul et al., (2001) in Nili-Ravi and Selvaraju et al., (2008) in Murrah buffaloes. On the other hand, the present value was lower than the values reported by Ahmed (2011) in Swamp buffaloes, Kumar et al., (1998) and Pratap et al., (1999a) in Murrah and Singh and Gupta (2008) and Beerendra et al., (2011) in Tarai buffaloes. The overall mean incidence of sperm head abnormalities in the present study $(1.23 \pm 0.10 \%)$ was comparable with the findings of Talukdar (2014) and lower than the value reported by earlier workers in Swamp buffaloes (Ahmed 2011, Dutta et al., 2007), in Murrah buffaloes (Singh et al., 1991, Selvaraju et al., 2008, Cheede et al., 2009). The overall mean percentage of mid-piece abnormalities $(0.79 \pm 0.06)$ was in close proximity with the values reported in Swamp (Ahmed 2011, Dutta et al., 2013) and Murrah (Selvaraju et al., 2008) buffalo bulls. However, the present value of mid-piece abnormalities was higher than that reported by Talukdar (2014) in Swamp buffalo and higher than the value reported by Murugavel et al., (2000) in Murrah buffaloes. The overall mean tail abnormalities $(6.12 \pm 0.29 \%)$ recorded in the present study was higher than the values reported by Selvaraju et al., (2008) and Ahmed, (2011) and Talukdar (2014).

The variation in ejaculate volume, mass activity, sperm motility and sperm concentration, percent HOST reacted sperm, Live sperm per cent, cold shock resistant sperm, sperm with intact acrosome and sperm abnormalities of head, mid piece and tail in different studies might be due to differences in species, breed, season and frequency of semen collection (Monji et al., 1980, Ahmed, 2011 and Dhami et al., 2011) etc. Statistical analysis revealed no significant difference in all fresh semen characteristics of four Swamp buffalo bulls except for HOST reacted sperm and percentage of intact acrosome. This could be due to evaluation and then selection of good quality ejaculates from different animals in the present study for biochemical and proteomic study.

\section{AST, ALT, Total Protein, Total Lipid and Total Cholesterol of seminal plasma of Swamp buffalo semen}

In the present study, the mean AST activity in seminal plasma of fresh semen ranged from $25.29 \pm 1.79$ to $27.19 \pm 1.41 \mathrm{U} / \mathrm{L}$ with an overall mean value of $26.05 \pm 0.74 \mathrm{U} / \mathrm{L}$. The AST activity in seminal plasma of Swamp buffalo bulls recorded in the present study was much lower than the value reported by Das et al., (2008) in Swamp buffalo bull semen of Assam (53.20 U/L) and Khawaskar et al., (2012) in Surti buffalo $(57.30 \pm 10.73 \mathrm{U} / \mathrm{l})$. The variation might be due to quality of ejaculates, difference in breed and species (Kumar et al., 1984) and method of processing for estimation of AST. Statistical analysis revealed no significant difference in AST activity in seminal plasma of fresh semen between Swamp buffalo bulls. This could be due to estimation of AST activity in selected good quality semen of different animals in the present study. In the present study, mean ALT activity in seminal plasma ranged from $48.35 \pm 2.53$ to $52.54 \pm 3.16 \mathrm{U} / \mathrm{L}$ with an overall mean value of $49.14 \pm 1.72 \mathrm{U} / \mathrm{L}$.

The ALT activity in seminal plasma of Swamp buffalo bulls recorded in the present study was higher than the values reported by Das et al., (2008) in Swamp buffalo of Assam and Khawaskar et al., (2012) in Surti buffalo. The ALT activities reported by Das et al., (2012) was 18.88 U/L and Khawaskar et al., (2012) was $15.38 \mathrm{U} / \mathrm{L}$. The variation might be due to use of good quality selected ejaculate used in the study, breed and species differences (Kumar et al., 1984) and the method of processing for estimation of ALT. 
Table.1 Fresh semen characteristics (mean* ${ }^{*}$ se) in different swamp buffalo bulls

\begin{tabular}{|l|c|c|c|c|c|}
\hline Characteristics & $\begin{array}{c}\text { Buffalo } \\
\text { Bull I }\end{array}$ & $\begin{array}{c}\text { Buffalo } \\
\text { Bull II }\end{array}$ & $\begin{array}{c}\text { Buffalo } \\
\text { Bull III }\end{array}$ & $\begin{array}{c}\text { Buffalo } \\
\text { Bull IV }\end{array}$ & \begin{tabular}{c} 
Overall*** \\
\hline AST (U/L)
\end{tabular} \\
\hline $25.29 \pm 1.79$ & $27.19 \pm 1.41$ & $25.97 \pm 1.37$ & $25.73 \pm 1.41$ & $26.05 \pm 0.74$ \\
\hline ALT (U/L) & $48.62 \pm 4.55$ & $52.54 \pm 3.16$ & $48.35 \pm 2.53$ & $47.04 \pm 3.44$ & $49.14 \pm 1.72$ \\
\hline $\begin{array}{l}\text { Total Protein } \\
\text { (mg/ml) }\end{array}$ & $3.45 \pm 0.02$ & $3.44 \pm 0.03$ & $3.47 \pm 0.03$ & $3.41 \pm 0.04$ & $3.44 \pm 0.02$ \\
\hline $\begin{array}{l}\text { Total cholesterol } \\
\text { (mg/d) }\end{array}$ & $23.08 \pm 1.27$ & $22.70 \pm 1.40$ & $25.35 \pm 0.87$ & $21.33 \pm 1.47$ & $23.12 \pm 0.65$ \\
\hline $\begin{array}{l}\text { Total Lipid } \\
\text { (mg/ml) }\end{array}$ & $2.06 \pm 0.11$ & $2.20 \pm 0.15$ & $2.46 \pm 0.11$ & $2.13 \pm 0.13$ & $2.20 \pm 0.07$ \\
\hline * 15 Observations, & $* * 60$ Observations & & & & \\
\hline
\end{tabular}

Table.2 Fresh semen characteristics (mean* \pm se) in different swamp buffalo bulls

\begin{tabular}{|c|c|c|c|c|c|}
\hline Semen characteristics & $\begin{array}{c}\text { Buffalo Bull } \\
\text { I }\end{array}$ & $\begin{array}{l}\text { Buffalo } \\
\text { Bull II }\end{array}$ & $\begin{array}{c}\text { Buffalo Bull } \\
\text { III }\end{array}$ & $\begin{array}{l}\text { Buffalo } \\
\text { Bull IV }\end{array}$ & Overall** \\
\hline Ejaculate volume (ml) & $1.54 \pm 0.05$ & $1.61 \pm 0.07$ & $1.55 \pm 0.07$ & $1.55 \pm 0.05$ & $1.57 \pm 0.03$ \\
\hline $\begin{array}{l}\text { Mass activity (0 to } 4+ \\
\text { scale) }\end{array}$ & 3.53 & 3.60 & 3.73 & 3.40 & 3.57 \\
\hline $\begin{array}{l}\text { Initial sperm motility } \\
(\%)\end{array}$ & $76.53 \pm 0.67$ & $75.12 \pm 0.34$ & $71.56 \pm 0.41$ & $74.54 \pm 0.47$ & $\begin{array}{c}73.45 \pm 0.2 \\
0\end{array}$ \\
\hline $\begin{array}{l}\text { Sperm concentration } \\
\text { (million/ml) }\end{array}$ & $\begin{array}{c}1100.00 \pm 25 \\
69\end{array}$ & $\begin{array}{c}1179.33 \pm 43 . \\
65\end{array}$ & $\begin{array}{c}1132.67 \pm 21 \\
72\end{array}$ & $\begin{array}{l}1140.67 \pm 2 \\
5.10\end{array}$ & $\begin{array}{c}1138.17 \pm 1 \\
5.20\end{array}$ \\
\hline $\begin{array}{l}\text { HOST reacted sperm } \\
(\%)\end{array}$ & $68.58^{\mathrm{b}} \pm 0.17$ & $77.87^{\mathrm{b}} \pm 0.94$ & $76.73^{\mathrm{ba}} \pm 0.90$ & $\begin{array}{c}76.73^{\text {a. }} \pm 0.9 \\
4\end{array}$ & $\begin{array}{c}76.97 \pm 0.4 \\
3\end{array}$ \\
\hline Live sperm (\%) & $83.36 \pm 0.43$ & $82.50 \pm 0.43$ & $83.36 \pm 0.44$ & $\begin{array}{l}82.16 \pm 0 \\
64\end{array}$ & $\begin{array}{l}82.85 \pm 0 \\
25\end{array}$ \\
\hline $\begin{array}{l}\text { Cold Shock resistance } \\
\text { index }(\%)\end{array}$ & $41.01 \pm 0.35$ & $40.28 \pm 0.43$ & $40.76 \pm 0.23$ & $40.41 \pm 0.39$ & $\begin{array}{c}40.62 \pm 0.1 \\
8\end{array}$ \\
\hline Intact acrosome (\%) & $82.56^{\mathrm{a}} \pm 0.49$ & $82.20_{4}^{\mathrm{ab}} \pm 0.2$ & $81.13^{\mathrm{ab}} \pm 0.34$ & $\begin{array}{c}82.13^{\mathrm{b}} \pm 0.3 \\
3\end{array}$ & $\begin{array}{c}82.01 \pm 0.1 \\
9\end{array}$ \\
\hline $\begin{array}{l}\text { Head abnormalities } \\
(\%)\end{array}$ & $1.00 \pm 0.18$ & $1.27 \pm 0.23$ & $1.33 \pm 0.18$ & $1.30 \pm 0.17$ & $1.23 \pm 0.10$ \\
\hline $\begin{array}{l}\text { Mid piece } \\
\text { abnormalities (\%) }\end{array}$ & $0.70 \pm 0.11$ & $0.83 \pm 0.13$ & $0.86 \pm 0.10$ & $0.77 \pm 0.11$ & $0.79 \pm 0.06$ \\
\hline $\begin{array}{l}\text { Tail Abnormalities } \\
(\%)\end{array}$ & $6.30 \pm 0.47$ & $5.77 \pm 0.68$ & $6.30 \pm 0.58$ & $6.10 \pm 0.59$ & $6.12 \pm 0.29$ \\
\hline
\end{tabular}

* 15 Observations, $\quad * * 60$ Observations

Means bearing different superscripts in a row differ significantly $(\mathrm{P}<0.05)$. 
Fig.1 SDS-PAGE of different molecular weight proteins in swamp buffalo semen

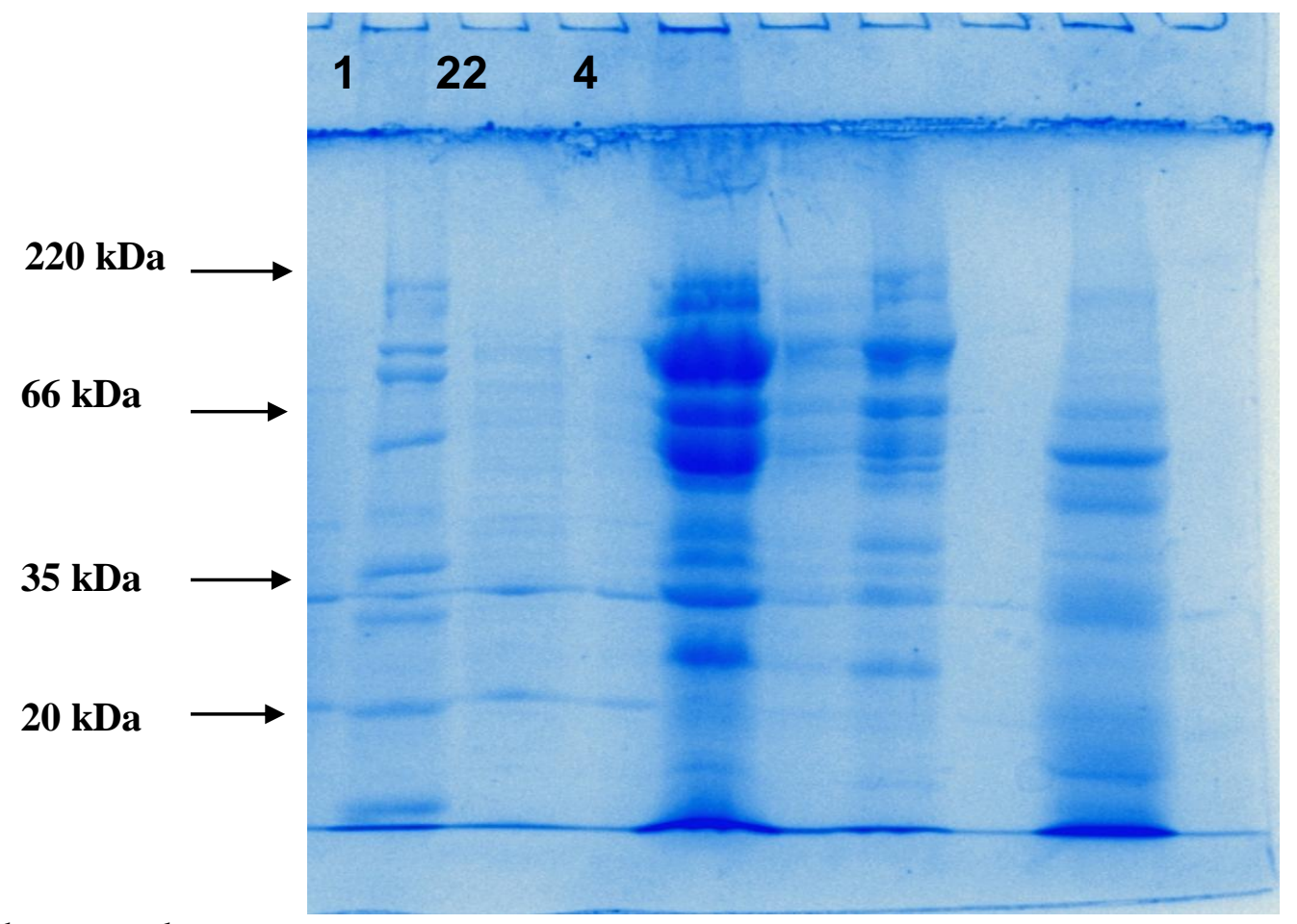

Lane 1: High range marker

Lane 2; Sperm membrane extract

Lane 3: seminal plasma of fresh semen

Statistical analysis revealed no significance difference in ALT activities of seminal plasma of fresh semen between Swamp buffalo bulls. This could be due to the fact that only good quality semen from each bull was selected in the present study.

Total protein concentration in seminal plasma of fresh semen and extracellular fluid of frozen semen of Swamp buffalo

In the present study, the mean seminal plasma protein concentration ranged from $3.41 \pm 0.04$ to $3.47 \pm 0.03 \mathrm{mg} / \mathrm{ml}$ with an overall mean value of $3.44 \pm 0.02 \mathrm{mg} / \mathrm{ml}$. Present finding was also similar to that of Das (2010), who reported the mean total protein concentration in seminal plasma of Swamp buffalo bull semen was $2.4 \mathrm{mg} / \mathrm{ml}$. The present value supports the finding of Borgohain (2016) who found that the mean total protein concentration in seminal plasma of bull was $3.5 \mathrm{mg} / \mathrm{ml}$. The mean total protein concentration of seminal plasma in fresh semen recorded in the present study was lower than the value $(1.78 \mathrm{~g} / \mathrm{dl})$ reported by Das et al., (2008) in Swamp buffalo. The variation might be due to the difference in age, breed and species of animals. Statistical analysis revealed no significant difference in total protein content in seminal plasma of fresh semen in different Swamp buffalo bulls used in the present study. This could be due to use of selected good quality semen from different animals in the present study.

In the present study, the mean seminal plasma cholesterol ranged from $21.33 \pm 1.47$ to $25.35 \pm 0.87 \mathrm{mg} / \mathrm{dl}$ with an overall mean value of $23.12 \pm 0.65 \mathrm{mg} / \mathrm{dl}$. The total cholesterol content found in the present study was in conformity with the finding of Jain and 
Anand (1976) and Nikam et al., (2005). Jain and Anand (1976) reported that the overall mean total cholesterol concentration in seminal plasma of buffalo bull was 24.7 $\mathrm{mg} / \mathrm{dl}$. Present value was also comparable with the range of overall mean total cholesterol concentration in seminal plasma of Murrah buffalo and Holstein Friesian bull was 19.37 and $27.82 \mathrm{mg} / \mathrm{ml}$ recorded by Nikam et al., (2005). The mean total protein concentration of seminal plasma in fresh semen was lower than the values reported by Shukla et al., (2009) and Das et al., (2010). The variation could be due to difference in age, species and breed of animals. Statistical analysis revealed no significant difference in total cholesterol in seminal plasma of fresh semen between Swamp buffalo bulls. This could be due to selection of equivalent quality of ejaculates from the bull under study.

In the present study, the mean total lipid content in seminal plasma ranged from $3.41 \pm 0.04$ to $3.47 \pm 0.03 \mathrm{mg} / \mathrm{ml}$ with an overall mean value of $3.44 \pm 0.02 \mathrm{mg} / \mathrm{ml}$. The mean lipid content in seminal plasma of fresh semen obtained in the present study was higher than that the value of $1.5 \mathrm{mg} / \mathrm{ml}$ obtained by Jain et al., (1976) in Murrah buffalo bull and $1.75 \mathrm{mg} / \mathrm{ml}$ recorded by Sarma et al., (1983) in buffalo bulls. Statistical analysis revealed no significance difference in total lipid in seminal plasma of fresh semen between Swamp buffalo bulls.

\section{Study of protein profiles of seminal plasma and sperm membrane extract of swamp buffalo semen}

In the present study, protein bands of different molecular weights ranging from $20-220 \mathrm{kDa}$ were observed in the seminal plasma, extracellular fluid and sperm membrane extract of fresh and frozen semen of Swamp buffalo. SDS-PAGE indicated presence of seven different protein bands with molecular weights of $25,28,38,55,65,71$ and $161 \mathrm{kDa}$ from seminal plasma of fresh semen from four different bulls. This study was comparable with the findings of Jobim et al., (2003), who observed seven to twelve spots of protein bands in sixteen numbers of Bosindicus and Bostaurustaurus adult bulls. Borgohain (2016) identified twelve protein spots in the bovine seminal plasma. Hazarika et al., (2013) reported the electrophoretic pattern of seminal plasma protein in SDSPAGE of yak revealed six major protein bands. The variable number of band might be due to species difference. The protein bands ranging from 25 to $104 \mathrm{kDa}$ in seminal plasma of bull might indicate higher fertility (Gary et al., 1993). The variable number of bands reported by different workers might be due to species differences and individual variations.

The band intensity of the $55 \mathrm{kDa}$ protein fraction was found to be higher in all the bulls. Killian et al., (1993) reported that seminal plasma of highly fertile bull contained $55 \mathrm{kDa}$ protein than in of low fertility bulls. Osteopontin is the $55 \mathrm{kDa}$ fertility associated protein in Holstein bull seminal plasma Cancel et al., (1997). The protein band with $55 \mathrm{kDa}$ identified might be the Osteopontin protein and all four Swamp buffalo bulls could probably be fertile bulls.

In this study, 25 and $28 \mathrm{kDa}$ protein bands were identified with high intensity in all four Swamp buffalo bulls. Manjunath (2002) reported that the bovine seminal plasma contained BSP, a $30 \mathrm{kDa}$ protein. However, Killian et al., (1993) reported that sample from Holstein bulls containing $26 \mathrm{kDa}$ protein indicated higher fertility. So the estimated protein band might be BSP and the all four bulls could be regarded as fertile bulls.

In the present study, 8 different protein bands were detected upon SDS-PAGE with 
molecular weights of $104,88,55,43,33,31$, 29 and $26 \mathrm{kDa}$ in sperm membrane extract (SME) of fresh semen of four different bulls. The present study was comparable with the findings of Borgohain (2016) who observed eleven protein bands with molecular weights of $25,30,39,45,79,85,92$ and $105 \mathrm{kDa}$ in SME of bull semen. Dixit et al., (2016) reported fourteen numbers of different molecular weight proteins in Bhadwari buffalo bulls ranged from 16 to $205 \mathrm{kDa}$. The variable number of bands reported by different workers might be due to species differences and individual variations.

Immunofluorescent analysis of ejaculated and caudaepididymal sperm showed Osteopontin (OPN) localization in a well-defined band in the postacrosomal region of the sperm head and also on the mid piece in Holstein bulls (Erikson et al., 2007). They reported that OPN existed at multiple molecular weight forms in the bull reproductive tract, 25, 35 and $55 \mathrm{kDa}$ respectively. Sauza (2013) reported that the OPN protein was both in seminal plasma and sperm membrane. In the present study, the protein bands with 25,35 and $55 \mathrm{kDa}$ molecular weights identified in SME might be the OPN protein and all four Swamp buffalo bulls could probably be regarded as fertile bulls. It was found that the band intensity of 28 and $30 \mathrm{kDa}$ protein was the highest in SME of all four bulls. The molecular weights of this protein bands were comparable to Heparin binding protein of 28 and $30 \mathrm{kDa}$ as reported by Karunakaran et al., (2013). They reported that bulls positive for heparin binding proteins in sperm membrane had higher chances of fertility. So the protein band with 28 to $30 \mathrm{kDa}$ observed in the present study might be Heparin binding protein and hence all four bulls could probably be recommended as fertile bulls. The mean values of AST (U/L) and ALT (U/L) activities, total protein $(\mathrm{mg} / \mathrm{ml})$, total cholesterol $(\mathrm{mg} / \mathrm{dl})$ and total lipid $(\mathrm{mg} / \mathrm{ml})$ in seminal plasma of fresh semen were $26.05 \pm 0.74, \quad 49.14 \pm 1.72, \quad 3.44 \pm 0.02$, $23.12 \pm 0.65$ and $2.20 \pm 0.07$ respectively.

\section{References}

Adeel, M., Ijaz, A., Aleem, M., Rehman, H., Yousaf, M. S. and Jabbar, M. A. 2009. Improvement of liquid and frozen thawed semen quality of Nili-Ravi buffalo bulls (Bubalus bubalis) through supplementation of fat. Theriogenology, 71: 1220-1225.

Ahmed, M. 2011. Effect of freezing rate and thawing method on quality of frozen buffalo semen. M.V.Sc. Thesis, Assam Agricultural University, Khanapara, Guwahati-22.

Asadpour, R., Alavi-Shoushtari, S. M., AsriRezaii, S. and Ansari M. H. K. 2007. SDS-polyacrylamide gel electrophoresis of buffalo bulls seminal plasma proteins and their relation with semen freezability. Anim. Reprod. Sci., 102:308-313.

Beerendra, S., Gupta, H. P. and Saxena, M.S. 2011. Studies on Physicomorphological characteristics and fertilizing ability of semen of Tarai buffalo bulls. Indian J. Anim. Reprod., 32 (2): 46-48.

Bhosrekar, M. R. 1990. Semen Production and Artificial Insemination. $1^{\text {st }}$ Edn., BAIF Development Research Foundation, 'Kamdhenu' SenapatiBapatMarg, Pune, 411016 (INDIA).

Blom, E. 1950.A simple rapid staining method for the differentiation between live and dead sperm cells by means of Eosin and Nigrosin. Nord. Vet. Med., 2: 58.

Borgohain, I 2016.Protein profiling and mRNA expression of bovine spermatozoa. M.V.Sc. Thesis, Assam 
Agricultural University, Khanapara, Guwahati-22.

Caballero, I., Vazquez, J. M., Garcia, E. M., Parrilla, I., Roca, J., Calvete, J. J., Sanz, L. and Martinez, E. A. 2008. Major proteins of boar seminal plasma as a tool for biotechnological preservation of spermatozoa. Theriogenology, 70: 1352- 1355.

Das, G. C., Deori, S., Das, B. K. and Goswami, R. N. 2007. Seminal characteristics of the Swamp buffalo of Assam. Indian Vet. J., 84: 1052-1053.

Das, P. 2010. Studies on certain physicochemical characteristics of semen of swamp buffalo (Bubalus carabenesis). M.V.Sc. Thesis, Assam Agricultural University, Khanapara, Guwahati-22.

Deori, S. 2015. Fertility associated membrane proteins and mrna expression in goat spermatozoa. Ph.D. Thesis, Assam Agricultural University, Khanapara, Guwahati-22.

Dhami, A. J. and Kodagali, S. B. 1988. Seminal characteristics and their interrelationships in Surti buffaloes. Indian Vet. J., 65: 61-64.

Dhami, A. J. and Sahni, K. L. 1994.Interferences of protein in cholesterol estimation of seminal plasma in the bovine. Indian J. Anim. Reprod., 15(1): 63-66

Dutta, J., Das, G. C., Roy, T. C., Deka, B. C., Das, P. K. and Bhattacharyya, B. N. 2013. A study on physical characteristics and sperm abnormalities of swamp buffalo bulls semen. In. Compendium of National Symposium on Buffalo for sustainable food security and Annual General Body meeting of Indian Society for Buffalo Development, on 15-16 March, 2013, Pp. 107.

Erikson, D. W., Way, A. L., Chapman, D. A. and Killian, G. J. 2007. Detection of osteopontin on Holstein bull spermatozoa, in caudaepididymal fluid and testis homogenates, and its potential role in bovine fertilization. Reproduction, 133: 909-917.

Frings, C. S. and Dunn, R. T. 1970.A colorimetric method for determination of total serum lipids based on the sulfophospho-vanillin reaction.Am. J. Clin. Pathol., 53(1):89-91.

Goularte, K. L., Gastal, G. D. A., Schiavon, R. S., Goncalves, A. O., Schneider, J. R., Corcini, C. D. and Lucia Jr., T.2014. Association between the presence of protein bands in ram seminal plasma and sperm tolerance to freezing. Anim. Reprod. Sci., 146: 165-169.

Gupta, H. P. and Misra, A. K. 2007. In vitro fertility of refrigerated buffalo spermatozoa. Indian Vet. J., 84: 11541155.

Hashemi, A., Arhoomand, P., Pirmohammadi, R. and Razzaghadeh, S. 2007. Effect of extender on sperm motility and acrosomal integrity of frozen buffalo semen. J. Anim.Vet. Adv., 6: 13401342.

Hazarika, D., Bhattacharya, D., Sarma, S., Baruah, K.K., Saikia, J. and Deori S. 2013 Sodium dodecyl sulphate (SDS)polyacrylamide gel electrophoresis of seminal plasma proteins in yak. Indian J. Anim. Sci., 83: 40-41.

Javed, M. T., Khan, A. and K, Razia. 2000. Effect of age and seasons on some parameters of Nili-Ravi buffalo bulls. VeterinarskiArhiv., 70: 83-94.

Karunakaran, M., Devanathan, T. G., Jawahar, T. P., Manimaran, K., Chitra, A., Dhali, A. and Selvaraju, S. 2012. Electrophoretic profile of bull sperm membrane proteins as a tool for selection of breeding bulls. Indian J. Anim. Sci., 82: 1303-1305.

Killian, G. J., Chapman, D. A. and Rogowski, L. A. 1993. Fertility - associated 
proteins in Holstein bull seminal plasma. Biol. Reprod., 49: 1202-1207.

Koonjaenak, S. 2006. Semen and sperm characteristics of Swamp buffalo bulls for A.I. in Thailand in relation to semen. Doctoral Thesis, Swedish University of Agricultural Sciences, Uppsala, Thailand.

Kumar, S., Tripathi, S. S. and Saxena, V. B. 1984.Effects of successive ejaculation on total protein, sialic and lactic acids and electrophoretic pattern of proteins of Red Dane, Jersey and Murrah bulls. Indian J. Anim. Sci., 54: 885-886.

Lowry, O. H., Rosebbrough, N. J., Farr, A. L., Randall, J. R. 1951. Protein measurement with the Follin phenol reagent. J. Biol. Chem., 193: 265-275.

Mahmoud, I.N. 1952. Some characteristics of semen of Egyptian buffalo bull. Faculty of Agri. Fouad.University of Cairo., 15: 16 (c.f. Anim.Breed.Abstr., 21: 1262.

Manjunath, P and Thérien, I. 2002. Role of seminal plasma phospholipid binding proteins in sperm membrane lipid modification that occurs during capacitation. J. Reprod. Immunol., 53: 109-119.

Mazumdar, H. 2012. Effect of additives on quality of frozen Swamp buffalo semen. M.V.Sc. Thesis, Assam Agricultural University, Khanapara, Guwahati-22.

Monji, Y., Ichinoc, K., Saitoh, H. and Waleri, E. G. 1980.Semen characteristics, sperm morphology and freezing of semen of River (Murrah) buffaloes in the Phillipines. Japanese J. Agric. Sci., 25: 187-193.

Nikam, S. R., Deshmukh, B. T., Vadnere, N. B., Nagvekar, A. S., Ingole, S. D. and Bharucha, S. V. 2005. Comparative appraisal of seminal plasma lipid profile in buffalo and crossbred. International $\mathrm{J}$. Cow Sci., 13(1-2), Print ISSN: 09711643.
Nordin, W., Hilmi, M. and Bongso, T.A. 1990.Semen characteristics relation to age in growing Swamp buffalo. Buffalo Journal, 6 (2): 161-166.

Pratap, N., Reddy, V. N. V., Sharma, P. A., Honnappa, T. G., Devraj, M., Krishnaswamy, A. and Arrora, V. K. 1999. Spermiogram and biochemical studies in Murrah buffalo bulls. Indian J. Anim. Reprod., 20 (2): 156-158.

Purohit, G. N., Singh, B., Vyas, S. K. and Yadav, S. B. S. 1998. Studies on sexual behaviour and seminal quality characteristics of Surti buffalo bulls and their interrelationships. Indian J. Agri. Res., 19: 62-63.

Rao, A. V. N. and Aryana, O. S. 1996. Seminal traits and frozen semen production in relation to age in Murrah bulls. Indian Vet. J., 73: 526-530.

Ravimurugan, T., Kanagarej, P. and Thangaraju, P. 2008.Frozen semen production potential of Murrah bulls. Theriogenology, 51: 1120-1125.

Reddy, N. S. S., Mohanarao, G. J. and Atreja, S. K. 2010. Effects of adding taurine and trehalose to a tris based egg yolk extender on buffalo (Bubalusbubalis) sperm quality following cryopreservation. Anim. Reprod. Sc., 119: 183-190.

Sarma B. C, Kaker M. L. and Razdan M. N. 1983.Total lipids and phospholipid in Buffalo semen (Bubalus bubalis). Theriogenology, 20(5): 521-527.

Selvaraju, S., Ghosh, J., David, C.G., Reddy, I.J. and Ravindra, J.P. 2008.Sperm nuclear morphology in relation to sperm functional tests in assessing buffalo semen. Indian Vet. J., 85: 505-507.

Shetti, A. B., Hukeri, V. B. and Deshpande, B. R. 1987. Semen characteristics and their relationship in Murrah buffalo. Indian. J. Dairy. Sci., 34: 108-110.

Singh, A. K., Brar, P. S., Cheema, R. S., Kaur, M. and Bansal, A. K. 
2014.Characterization of buffalo bull frozen-thawed sperm proteins through SDS-PAGE and their correlation with HOST and in vitro acrosome reaction. Indian J. Anim. Reprod., 84(9): 949953.

Singh, B. and Gupta, H. P. 2008. Physical and morphological parameters of Tarai buffalo sperm during cryopreservation. Indian Vet. J., 85: 733-735

Singh, M., Upadhyay, M. P. and Pant, H. C. 1994.Effect of cold shock on certain seminal characteristics of buffalo bulls under temperate climate. Indian Vet. Med. J., 18: 72-75.

Sukhato, P., Thongsodseang, S., Utha, A. and Songsasen, N. 2001.Effect of cooling and warming conditions on post thaw motility and fertility of cryopreserved buffalo spermatozoa. Anim. Reprod. Sci., 67: 69-77.

Talukdar, D. 2014. Morphological and functional characterization of in vitro capacitated and frozen thawed swamp buffalo spermatozoa. Ph.D. Thesis,
Assam Agricultural University, Khanapara, Guwahati-22.

Tomar, N. S. and Misra, B. S. 1971.Comparative analysis of nonmotile and progressively motile semen of buffalo bulls. Indian Vet. J., 48: 702705.

Tomar, S. S., Singh, S.P. and Pandit, R.K. 2000.Freezability of buffalo semen in mini straws.

Vyawanare, R., Chauhan, R. A. S., Nema, S. P. and Porwal, M. L. 1989.Studies on seminal attributes, enzyme leakage and preservability of buffalo semen. Indian Vet. J., 66: 1128-1132.

Wang, X., Kaya, A. and Memili, E. 2010.Spermatozoal protein markers for Angus bull fertility. Reprod. Fert. Dev., 23: $198-198$.

Yang, D. Y., Liu, L., Chen, X., Speller, C. F. 2008. Wild or domesticated: DNA analysis of ancient water buffalo remains from north China. J. Archaeol. Sci., 35:2778-2785

\section{How to cite this article:}

Manna Baruti, B. C. Deka, Manjyoti Bhuyan, Shantanu Tamuly, R. K. Biswas and Sinha S. 2018. Biochemical Characterization of Swamp Buffalo (Bubalus carabanesis) Semen. Int.J.Curr.Microbiol.App.Sci. 7(06): 2618-2629. doi: https://doi.org/10.20546/ijcmas.2018.706.310 